Endocrinol. Japon. 1988, 35 (3), 503-509

NOTE

\title{
A Case of Large Prolactinoma Supposed to be Cured by Bromocriptine Therapy
}

\author{
KAZUnORi ARITA, TOHru UOZUMI AND Masahiro OHTA \\ Department of Neurosurgery, Hiroshima University \\ School of Medicine, Hiroshima Japan
}

\begin{abstract}
The authors reported a patient with a large prolactinoma (PRL 1,716 $\mathrm{ng} / \mathrm{ml}$ ) who was treated with bromocriptine for two years and followed up for a subsequent 36 months. After the start of the therapy, the tumor size was dramatically reduced, and finally the disappearance of the tumor was confirmed by high resolution coronal CT. The serum prolactin level and pituitary function were normalized. The tumor has not regrown and the blood prolactin level has remained normal for 36 months since the discontinuation of bromocriptine administration. This is a very rare case report on the eradicative effect of bromocriptine on such a large prolactinoma.

Another characteristic of this case was that the prolactin reserve was maintained not only before the therapy but also during the early stage of the therapy.
\end{abstract}

Bromocriptine can cause both a reduction in tumor size and a decrease in blood prolactin in many prolactinomas. However, it is well known that the discontinuation of bromocriptine usually results in a new increase in blood prolactin and regrowth of the tumor. So bromocriptine has generally been considered a non-eradicative therapeutic agent for prolactinoma.

The authors examined a patient with a large prolactinoma which was cured radically by bromocriptine therapy.

\section{Case}

This 39-year-old man was well until February 1981 when he became aware of left visual disturbance. The visual acuity of his left eye was $20 / 40$. His right visual acuity was $20 / 16$, but this also began to fail at the beginning of August 1981. Thereafter, he sometimes suffered from headaches and his visual acuity became worse. He was then referred to the Department of Neurosurgery, Hiroshima University Hospital, and admitted on September 4th, 1981.

\section{Received November 20, 1987}

Address reprint request to: KAZUNORI ARITA, M. D., Department of Neurosurgery, Hiroshima University, School of Medicine, 1-2-3 Kasumi, Minami ward, Hiroshima 734, Japan.

\section{Examination}

He was in normal general condition, 163 $\mathrm{cm}$ in height and weighed $72 \mathrm{~kg}$. Visual 


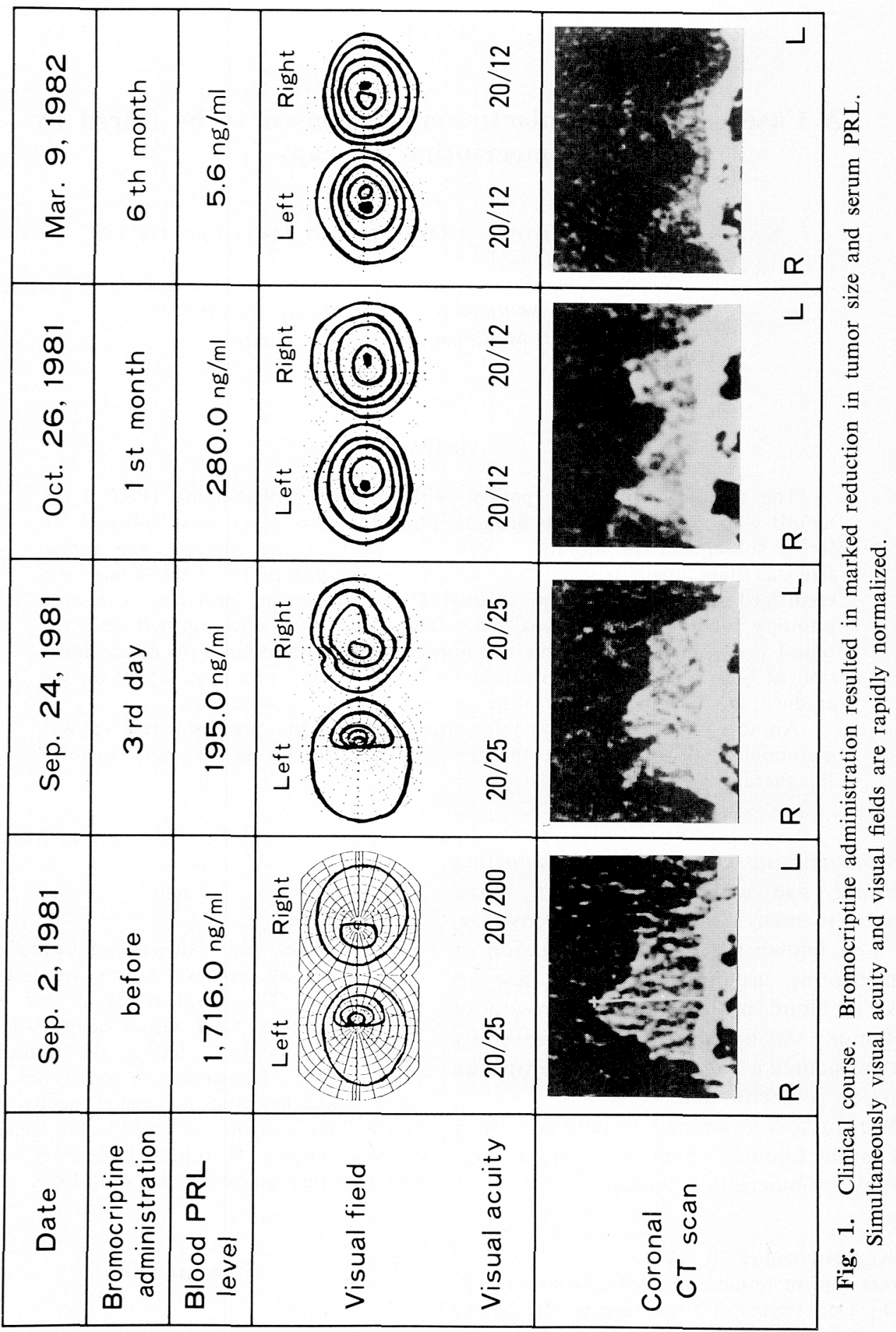


acuity was $20 / 100$ in the right and 20/22 in the left eye. Visual field examination showed a typical bitemporal defect (Fig. 1). The other neurological examinations were normal. Skull X-ray films showed enlarged sella turcica with a volume of $2800 \mathrm{~mm}^{3}$ (Dichiro) and a double floor. Tomography revealed deepening and destruction of the sellar floor especially on the left side.

Coronal CT scan demonstrated a pituitary tumor of slightly high density with supra- sellar expansion (Fig. 1). The tumor was enhanced homogeneously by contrast medium. The maximum height on the coronal CT scan of this tumor was $28 \mathrm{~mm}$.

Bilateral carotid angiography was normal except for a pocket formation in the left carotid siphon.

The blood prolactin level was $1,716.0$ $\mathrm{ng} / \mathrm{ml}$. Basal concentrations of other pituitary hormones were normal. Poor response of growth hormone (GH) in an insulin-tolerance

\begin{tabular}{|c|c|c|c|c|c|c|c|c|c|c|c|c|c|}
\hline \multirow{3}{*}{$\begin{array}{l}\text { Bromocriptine } \\
\text { administration }\end{array}$} & \multirow{3}{*}{ Date } & \multicolumn{4}{|c|}{ ITT } & \multicolumn{4}{|c|}{ TRH TEST } & \multicolumn{4}{|c|}{ LHRH TEST } \\
\hline & & \multicolumn{2}{|c|}{$\underset{(\mathrm{ng} / \mathrm{ml})}{\mathrm{GH}}$} & \multicolumn{2}{|c|}{$\mid \begin{array}{c}\text { Cortisol } \\
(\mu \mathrm{g} / \mathrm{dl})\end{array}$} & \multicolumn{2}{|c|}{$\begin{array}{l}\text { TSH } \\
(\mu \mathrm{U} / \mathrm{ml})\end{array}$} & \multicolumn{2}{|c|}{$\underset{(\mathrm{ng} / \mathrm{ml})}{\mathrm{PRL}}$} & \multicolumn{2}{|c|}{$\begin{array}{c}\mathrm{LH} \\
(\mathrm{mlU} / \mathrm{ml})\end{array}$} & \multicolumn{2}{|c|}{$\mid \begin{array}{c}\mathrm{FSH} \\
(\mathrm{mlU} / \mathrm{ml})\end{array}$} \\
\hline & & Base & Peak & Base & Peak & Base & |Peak & Base & Peak & Base & |Peak & Base & Peak \\
\hline before & Sep. 5,1981 & 2.2 & 3.2 & 17.3 & 23.2 & 2.5 & 3.0 & $1,716.0$ & $6,226.0$ & 3.6 & 34.6 & 6.2 & 11.3 \\
\hline 1 month & Oct. 22,1981 & 0.9 & 4.9 & 12.3 & 26.0 & 2.3 & 10.8 & 155.0 & $1,215.0$ & 5.3 & 71.1 & 3.5 & 9.0 \\
\hline 8 months & May. 13,1982 & 2.3 & 15.1 & 9.9 & 20.2 & 2.8 & 10.5 & 3.9 & 10.3 & 15.8 & 57.3 & 10.5 & 14.3 \\
\hline $\begin{array}{l}2 \text { years and } \\
8 \text { months }\end{array}$ & May. 12,1984 & 0.4 & 31.7 & 8.3 & 17.4 & 2.9 & 10.1 & 4.4 & 5.9 & 8.2 & 48.9 & 8.6 & 15.4 \\
\hline $\begin{array}{l}9 \text { months after } \\
\text { discontinuation }\end{array}$ & Mar. 16,1985 & 3.1 & 22.5 & 9.9 & 22.6 & 2.5 & 6.1 & 8.8 & 12.1 & 18.2 & 68.4 & 10.0 & 16.1 \\
\hline
\end{tabular}

Fig. 2. Changes in pituitary hormonal function.

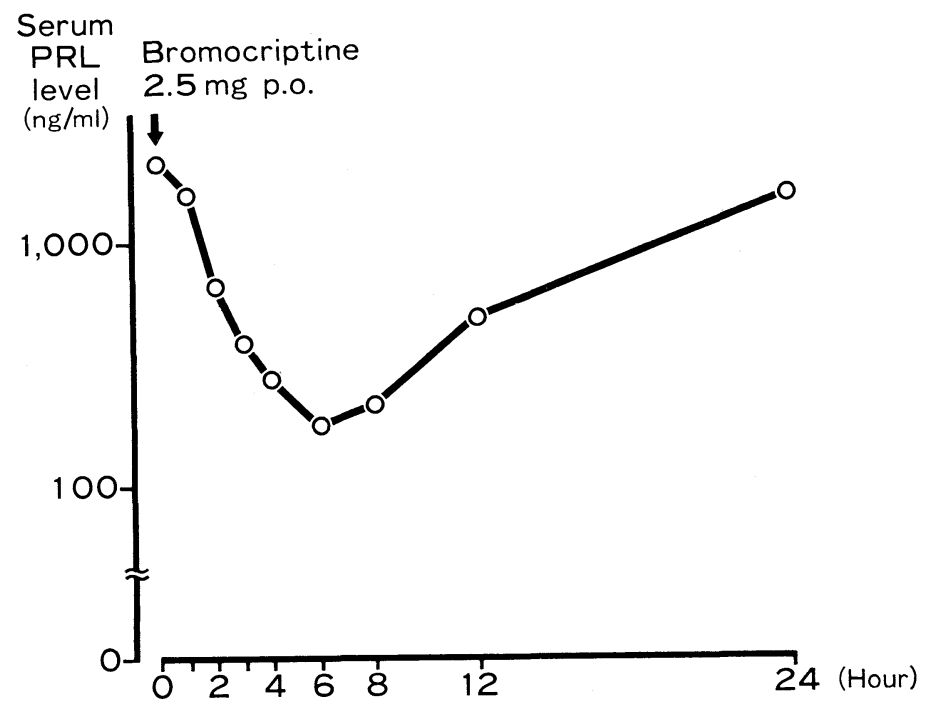

Fig. 3. Results of the CB-154 test (bromocriptine $2.5 \mathrm{mg}$ ). PRL level reduced onetenth of the basal concentration. 
test and thyroid stimulating hormone (TSH) in a thyrotropin releasing hormone (TRH) test was observed. Blood prolactin was increased to four times $(6,226.0 \mathrm{ng} / \mathrm{ml})$ the basal concentration $(1,716.0 \mathrm{ng} / \mathrm{ml})$ by intravenous injection of TRH $(500 \mu \mathrm{g})$ and decreased to one-tenth $(198.0 \mathrm{ng} / \mathrm{ml})$ of the basal prolactin concentration 6 hours after a single administration of bromocriptine (2.5 mg) (Fig. 2, 3).

\section{Therapeutic course}

This tumor was diagnosised as a large prolactinoma. The administration of bromocriptine $(5 \mathrm{mg} /$ day $)$ was started October 22 1981. The dosage of bromocriptine was gradually increased to $15 \mathrm{mg} /$ day.

Two days after the start of the therapy (total dose of $10 \mathrm{mg}$ ), the patient became aware of some restoration of visual acuity. Visual acuity of his right eye was improved to $20 / 25$. The blood prolactin level was reduced to $195.0 \mathrm{ng} / \mathrm{ml}$. CT scan revealed a slight reduction in tumor size (Fig. 1).

One month after the start of the therapy, visual acuity and the visual field were completely normalized. The blood prolactin level was $280.0 \mathrm{ng} / \mathrm{ml}$. CT scan revealed a considerable reduction in the tumor size. The height of the tumor was $17 \mathrm{~mm}$.

Six months after the start of the therapy, blood prolactin was normalized $(11.0 \mathrm{ng} / \mathrm{ml})$. CT scan demonstrated the complete disappearance of the tumor and the development of empty sella.

Two years and 9 months after the start of the therapy, blood prolactin stayed within the normal range during the $15 \mathrm{mg} / \mathrm{day}$ administration of bromocriptine (Fig. 4). Bromocriptine administration has been discontinued since June 29th 1984.

At present, 36 months after the discontinuation, blood prolactin remains normal. High resolution $\mathrm{CT}$ revealed that the tumor has not recurred.
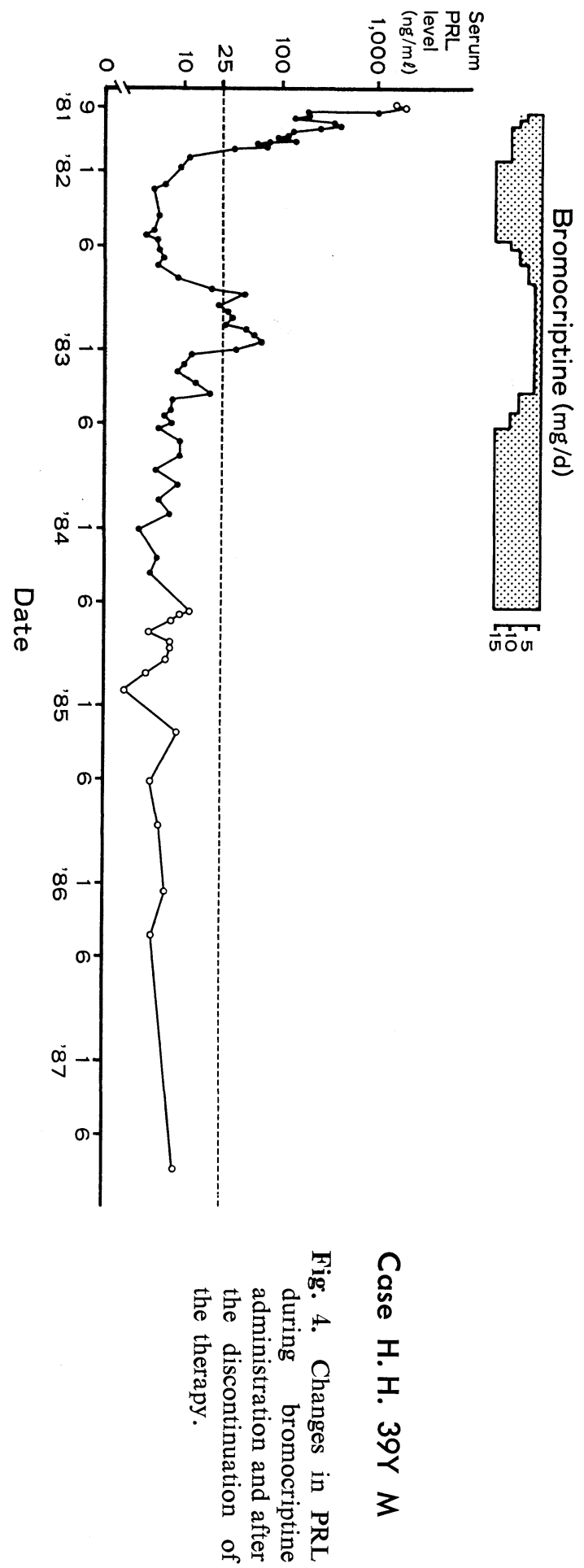


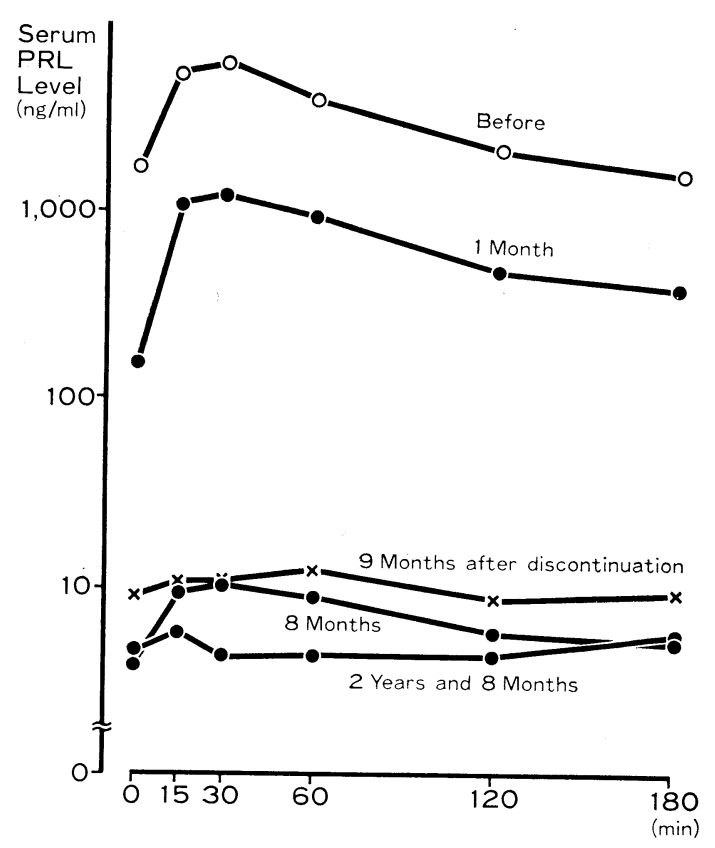

Fig. 5. Changes in PRL response to TRH test. PRL reserve was maintained until 8 months after the start of the therapy.

With regard to the reserve function of pituitary hormones, stimulation tests revealed poor response of $\mathrm{GH}$ and TSH before therapy. One month after the therapy, TSH reserve was normalized, and 8 months after the start, GH reserve was also normalized. Since then, the reserve functions of $\mathrm{GH}$ and TSH have been normal. (Fig. 2)

The response of prolactin to $\mathrm{TRH}$ stimulation was maintained not only before the therapy but during the early stage of the therapy (Blood prolactin increased to more than twice the basal concentration). But since the last stage of the therapy, prolactin reserve has deteriorated. (Fig. 5)

\section{Discussion}

Bromocriptine administration is widely accepted to have a prolactin reducing effect and tumor size reducing effect (Bonneville et al., 1982; Dallabonzana et al., 1984;
Eversman et al., 1979; Matsumura et al., 1981; Nillius et al., 1978). These effect were thought by Rengachery et al. (1982) and Tindall et al. (1982) to be due to reversible inhibition of the protein-synthetic machinery and the marked reduction in the cytoplasmic volume.

However, the authors argued that these effect were attributed to both a cytocidal effect on bromocriptine-sensitive cells and a cytostatic effect on bromocriptine-resistant cells based on microscopic and electromicroscopic findings (Gen et al., 1983ab). And the possibility of a truly curative effect on the prolactinoma, if it consists of bromocriptine-sensitive cells alone, was suggested (Gen et al., 1983a)

Usually prolactin increases again to a considerable concentration after discontinuation of bromocriptine therapy (Bergh et al., 1981; Thorner et al., 1981). Our own experience has shown that prolactin increases again to the pretreated level in almost all cases. This is therefore a rare case showing an eradicative effect of bromocriptine on a large prolactinoma (PRL $1716.0 \mathrm{ng} / \mathrm{ml}$ ). The responsiveness of this tumor to bromocriptine therapy is considered to be attributed to the high percentage of bromocriptinesensitive cells and the large amount of bromocriptine administrated $(10,775.5 \mathrm{mg}$ in total). We can say this is exactly the type of case that we suggested in the above mentioned study.

Recently some authors reported similar cases. Zárate et al. (1983) reported 6 cases in which prolactin levels remained normal for two years after bromocriptine discontinuation. Teramoto et al. (1980) and Moriondo et al. (1985) reported similar cases. As for large prolactinoma, Nissim et al. (1983) reported that persistent normalization of serum prolactin was obtained in 3 out of 32 cases treated with bromocriptine (Follow up period: 12 months). Dallabonzana et al. (1984) reported that persistent normalization of serum prolactin was obtained in only 
one patient out of 26 large prolactinoma cases (Follow up period: 12 months).

There is the possibility of a complete cure of the large prolactinoma by bromocriptine therapy as in this case, though it may be a very rare. In the near future, with an increase in the number of cases of large prolactinoma treated with bromocriptine and followed up for a long term, the real frequency of complete cure by bromocriptine therapy will become clear.

Blood prolactin response to $\mathrm{TRH}$ of prolactinomas is generally considered to be insignificant (Assies et al., 1980). In our own experience with 83 prolactinomas, prolactin reserve was maintained (blood prolactin increased to more than twice the basal concentration after TRH iv) in only 4 cases before treatment. Furthermore bromocriptine is regarded as suppressing the prolactin reserve. So it is remarkable that the prolactin reserve was maintained before therapy and during the early stage of the bromocriptine therapy in this case. As it is generally accepted that GH secreting adenomas which respond positively to TRH test are usually bromocriptine-sensitive (Liuzzi et al., 1974), similarly we might say that the prolactinoma with positive prolactin response to TRH test, as in this case, may be bromocriptine-sensitive. If that is true, such prolactinomas might be expected to be treated radically by bromocriptine therapy. The conclusion should be deferred until more of such cases are observed.

\section{References}

Assies, J., A. P. M. Schellekens and J.L. Touber (1980). The value of an intravenous TRH test for the diagnosis of tumoral prolactinemia. Acta Endocrinol. 94, 439-449.

Bergh, T., S. J. Nillius and L. Wide (1981). Return of prolactin hypersecretion after cessation of bromocriptine therapy of hyperprolactinemic amenorrhoea. Neuroendocrinol. Lett. $3,284$.
Bonnenille, J. F., D. Poulignot, F. Cattin, M. Couturie, E. Mollet and J. L. Dietmann (1982). Computed tomographic demonstration of the effects of bromocriptine on pituitary microadenoma size. Radiology 143, 451-455.

Dallabonzana, D., G. Oppizi, G. Verde M. T. Marsili, P. G. Chiodini, A. Liuzzi and G. Luccarelli (1984). Long term effects of the medical treatment of macroprolactinomas. $J$. Endocrinol. Invest. 7, (Suppl 1), 31.

Eversmann, T., R. Fahlbush, H. K. Rjosk and K. Wereder (1979). Persisting supression of prolactin secretion after a long-term treatment with bromocriptine in patients with prolactinomas. Acta Endocrinol. 92, 413-427.

Gen, M., T. Uozumi, S. Shinohara, M. Naito, A. Ito, S. Mori, H. Kajiwara (1983a). Dose bromocriptine has a cytocidal effect on prolactinoma cells. Neurol. Med. Chir. 23, 6165.

Gen, M., T. Uozumi, M. Ohta, A. Ito, H. Kajiwara and S. Mori (1983b). Necrotic changes in prolactinomas after long term administration of bromocriptine. J. Clin. Endocrinol. Metab. 59, 463-470.

Liuzzi, A., P. G. Chiodini, L. Botalla, F. Silvestrini and E. E. Müller (1974). Growth hormone (GH)-releasing activity of TRH and $\mathrm{GH}$-lowering effect of dopaminergic drugs in acromegaly: Homogeneity in the two responses. J. Clin. Endocrinol. Metab. 39, 871876.

Matsumura, M., S. Mori and T. Uozumi (1981). Size reduction of a large prolactinoma by bromocriptine treatment. Report of a case. Neurol. Med. Chir. 21, 127-130.

Moriondo, P., P. Travaglini, M. Nissim, A. Conti and G. Faglia (1985). Bromocriptine treatment of microprolactinomas: Evidence of stable prolactin decrease after drug withdrawal. J. Clin. Endocrinol. Metab. 60, 765-772.

Nillius, S. J., T. Bergh, P. O. Lundberg, J. Stahle and L. Wide (1978). Regression of a prolactin-secreting pituitary tumor during longterm treatment with bromocriptine. Fertil. Steril. 30, 710-712.

Nissim, M., B. Ambrosi, C. Giovine, P. Moriondo, P. Travaglini and G. Faglia (1983). Outcome of patients with macroprolactinomas after bromocriptine withdrawal. Acta Endocrinol. 103 (Suppl. 256), 86.

Rengachery, S. S., T. Tomita, B. F. Jefferies and I. Watanabe (1982). Structural changes 
in human pituitary tumor after bromocriptine therapy. Neurosurgery 10, 242-251.

Teramoto, A. and K. Takakura (1985). Relative high dose bromocriptine administration to prolactin producing pituitary adenoma. Folia Endoclinologica Japonica 16, 432. (in Japanese) Thorner, M. O., R. L. Perryman, A. D. Rogol, B. P. Conway, R. M. Macleod, I. S. Login and L. Morris (1981). Rapid changes of prolactinoma volume after withdrawal and reinstitution of bromocriptine. J. Clin. Endocrinol. Metab. 53, 480-483.
Tindall, G. T., K. Kovacs, E. Horvath and M. O. Thorner (1982). Human prolactin-producing adenomas and bromocriptine: A histological, immuno-cytochemical, ultrastructural and morphometric study. J. Clin. Endocrinol. Metab. 55, 1178-1183.

Zárate, A., E. S. Canales, C. Cano and C. J. Pilonieta (1983). Follow up of patients with prolactinomas after discontinuation of long term therapy with bromocriptine. Acta Endocrinol. 104, 139-142. 